\title{
現代社会の動 向と造園
}

\section{はじめに}

未来は過去からの連続した存在であるかぎり，今後の 造園の在り方に大きな影響を与える要因の中で, 過去の 造園活動の果した役割と位置を重視せざるを得ないのは 当然であ万う。将来にバラ色の夢を托すのは自由である が，それを単なる夢で終らせないだけの意義づけも必要 である。その意味で，21世紀までの10余年の展望も過去 20年余の経過の延長の上渵かれることにならら。

1964年以来21年ぶりに I F L A 日本大会が開催される ことになった。今回の日本大会開催の意義については， 既に少しく触れているが4)，これを機会にこの20余年間 の日本の造園界の動向を顧みる契機とすることも必要で 两る。この 20 年余の間汇何が解決され, 何が課題として 残っているかを自らの問題意識の中で問い直す作業をこ の際してみようというのが本稿の趣旨である。

\section{1. 過去20年間の造園活動}

過去の造園活動の成果と課題を整理与るために，第 9 回ＩＦＬＡ日本大会（1964年）の際に出版された「日本 の造園」において, 当時筆者の意識に絮った造溒の課題 がそとの後どの上らな経過をたどったか在追ってみた $(3)$ 。

造園の課題としては造園活動全般に対なるもの, 都市 域・工業地域・農村地域・自然地域のそれぞれに関寸る ものとに分けて把兄てみる。

造園活動に関する認識の問題には, 今日の環境創造活 動に伝統をいかに生かすか，歴史的空間造形技術をいか に公共空間に生か寸か, 庭園的空間加都市的, 国土的 スケールに造園活動の対象をいかに伸展させるか, 環境 形成に際して計画チームの一員として積極的に参加して い忛るかがあげられていた。環境問題等において一部境 界領域への参加がみられたものの，上記の諸点は今なお 残された課題であるといってよい。

都市域の生活環境整備汇関する課題としては, 新しい 都市環境像を構築すること, 公園緑地問題を全体の土地 利用計画の中に位置づけ整備すべきこと, 公害の防止な

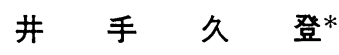

らびに予防の推進, 臨海部の環境回復等が考兄られてい た。都市域の公園緑地政策に関してはその後, 緑のマス タープランの施策, シビルミニマム思想の普及, さらに は最近は快適環境の創出をめざす環境管理計画の策定の 動きがみられる。制度面沉ついてもこの間に近郊緑地保 全, 歴史的風土保全, 都市公園整備緊急措置, 都市緑地 保全，生産緑地保全をはじめ，公害対策関係等の諸法律 が成立し, 公園緑地行政的には明治以来最も活況を呈し た時期といって過言でなからら。問題はこれらの諸制度 が今後共にいかに有効に活用されていくかにかかってい る。また最近の特徴としては公園緑地等の面的整㣁の久 でなく, 緑の量の確保・増大, 緑の質の向上およびこれ らを保証する社会経済的条件の整備にも関心が高まり， 都市居住環境を緑といら側面からも整備していこらとす る動きが加わってきた。しかも緑への住民の関心も強い ことからこの状沉をいかに持続させるかが重要になっ てくる。一般に環境の問題は限界活動之される。より社 会的に重要な問題（戦争，不況等）が生じる之最初に切 りつめられるといら宿命をもっている。したがって環境 改善・向上のための計画, 諸制度が十分汇定着し, 一般 の人々の水続的支持を得られるように慣習化し, 意識が 遣伝的に継承されるようにして扔か权ばならない。この ことは21世紀までのこれからの最大の課題である。

工業地域の整備については, 新産業都市に代表される 地方都市整備汇括计る広域緑地計画策定はレクリエーシ ョン, 自然保護, 景観保全から行われるべきこと, 埋立 地の工場立地漈してはそのマスタープランの中に公園 緑地の配置はもとより，環境保全計画をもつべきことが 指摘されていた。これらに関しては緩衝緑地制度, 工場 立地法による緑化規定，環境乃セスメントなどによる対 応があり, 大規模な工場, 計画的工業地域については徐 々に成果が上ってきていると思わ机るが，中小・零細工 場等の緑環境は今だに劣悪な状沉にある。また原子力利 用を含めたエネルギー関連企業の立地之環境保全の問題 も，造園家のそれへの対応の仕方も含めて未解決の課題 といってよかろう。

農村地域においては1960年代には八郎潟干拓をはじめ

* 東京大学農学部 
とする新農村建設計画と既存農村の再整備への抬動がみ られるが後者はあまり意識されていなかった。新農村建 設に際してはオランダ等海外の事例の影響やドイッの農 村土地利用計画手法 ${ }^{1)}$ を参照しながら農村緑地計画の必 要性が主張された。農村にお汀る生活環境保全は江戸後 期以降関心が薄く, 明治以後も生産環境整備優先のた め, 極めて遅れた状態にあった。その背景として生産的 緑の多い農村で, 今さら緑地計画の必要性もないという 意識が，多くの農林業関係者の間にあったからである。 このことは今日といえども意識としては根強く継続して おり, 農村の緑地問題は常に二義的, 付加的に考慮され る傾向にある。この状況が，わが国の農村環境整備を遅 らせている最大の要因と考えられる。既存農村の再整備 については農業構造改善事業の一環として，緑の村整 備, 農村公園・スポーツ施設整備が行われてきている が，これからの施策の基本的姿勢も結果として農家の所 得向上に役立つものであるとの認識から出発している。 したがって農村地域を今後造園家が活動対象としていく とき自然環境, 生活環境の保全・整備のみならず，当然 のことながら生産環境の整備を含めて考えていかねばな らないであろら。

自然地域の保全と開発も大きな課題であった。20年前 の意識としては自然保護と経済的価值の調和をいかにす るか, 産業 (電源) 開発と自然景観の保謢, 秃山緑化, 観光開発による自然資源の破壊をどうするか等が問題視 されていた。これらについてはその後, 道路建設と植生 破壞についての研究, 環境アセスメントの施行, 自然環 境保全法の成立と各種自然環境調査の実施を通して人々 の自然地域の保全への関心は高まってきているといえ る。

このようにみてくると, 制度ができ計画が進んだもの はいわゆる環境問題として紙上で話題になったものが多 いことがわかる。すなわちこの 20 年間の造園界の成果と いえるものは主として環境悪化, 環境破壊の哚刻さの故 にその対応策として生まれてきたといら面が強い。いわ ば他力本願的成果ともいうべきものであって造園家の努 カによって世論をリードし獲得したといら感が稀薄であ る。しかもその多くは環境の保護・保全を中心としたも のであって, 環境を新たに創り出し構筑していくという ものではなかった。その表われとして、この間にわれわ れは歴史的に評価され得る作品 (広義の創造活動) を果 して残したであろうかと自問するとき，極めて否定的に ならざるを得ない。文化創造の役割の一端を担うべき造 園家が, 調査や下請の仕事の忙しさにかまけて本来の創 作努力を忠っていたとすれば問題である。今後はより良 い，快適な居住環境の創造をめざして空間創造の面から も試行を積み重视る機会を多くすることが必要となって こよう。創作活動を通して文化を創るという自負をもっ
と強く持った方がよいのではないだろうか。

\section{2. 従来の思考方式の限界}

今後の造園界を考えるに当たって前述の積み残しの課 題の解決之同時媇た媇生じるであるら社会動向に対処 して，如何に行動すべきかを考えねばならない。その際 に従来とられていた常套手段としての解決方式が今後必 ずしも使えないということは留意しておかねばならな い。経済審議会は 21 世紀の日本を展望するに当たって次 の三点の思考方式の限界を指摘している ${ }^{6)}$ 。

第 1 は欧米先進国範を求めそれを導入することによ って前進をはかろうとするいわゆるキャッチアップ型思 考は今後成立たないことである。もちろん，まだ手本を 必要とする分野に打いては有効であるうし，また説得材 料として海外紹介が有用な間はこの思考方式が利用され るであろう。しかし一般的には手本はなくなったといっ てょく, 独自の環境㓣造の道を求めね杖ならない時期比 至っている。端的汇は公害先進国として自ら解決汇乘り 出さ权ばならなかったことなどは先駆的な例 とい光よ う。しかしながら短時日で独自の日本的環境創造方式を 実現させることが難しいなら，当面は欧米事例にヒント を得て日本化の試及が進むものと思われる。このやり力 なら長年日本人の慣れ親しんだ手法だからである。この 場合にも，いわゆる日本的なるものとは何かという疑問 が常に残ることになる。日本的環境観の把握から出発す る必要がでてくるのである。

第 2 は抎大成長によって問題黄解決する方式が不可能 になってきたことである。従来のように規模の扗大，量 の増大をはかること，しかもそれを短期間で奏現させる といら目標設定そのものが難しくなってきたことであ る。このことは後発の公園緑地関倸にとっては大変な痛 手である。創出すべき緑とオープンスペースの量的確保 が十分に進まないらちに予算的制約が生じてくる技それ があるからである。しかし一方で全体の開発の速度が低 下すれば保全すべき緑の確保には有利激くことになる う。したがって今後は緑の減少を可及的に抑光, 緑や才 ープンスペースの質の向上，効果的な配置などにより関 心が向くものと思われる。その意味では搪大成長の論理 から新た汇保全の論理を構築しなければならないである 5。

第 3 は仲間内の小国の論理が通用しなくなることで亦 る。狭い領域の中でしか通用しない論理で行動する甘兄 は許されなくなる。国際的, 学際的視野が要求されてく る。国際競争において，また国内でも境界領域的仕事に 積極的に参加していくためには新たな視点が要求され る。これまでの慣例でいえば独自の論理によっていかに 早く多勢の専門家が仕事に着手したかによって境界領域 の職域的プライオリティが確立する。またそれと併行し 
て新しいネットワーキングも必要になってくる。同一分 野の仲間だけの単なる集団でなく新たに広領域にわたる 学際的な人的結合の組織化が重要となる。いつの世にお いても人的資源は最大の資産となるからである。

\section{3. 今後の社会動向と造園}

1）環境への基本的要求

人々が緑の環境に対して要求・期待する内容のうち, 社会状況の变化に際しても比較的変らない事柄として以 下の諸点があげられる22。

第 1 は生存を保証するものである。これは安全を確保 し，健康をまもり，食糧供給を行うなどが含まれる。す なわち人々が生存していくために必要な条件としての緑 環境である。防災緑地，保健のための緑地，生産緑地な ぞが対象となろう。

第 2 は資源を維持するためのもので，将来ないしは子 孫のために必要な緑の資源, 歴史的遣産を保全すること である。自然文化財・歴史的風土の保全や保存緑地など が相当する。

第 3 は人々の向上・発展しようとする欲求を充たすた めに必要なもので，快適居住環境の形成のために必要な 緑, 都市美観に寄与するような緑などが対象としてあげ られるであろう。

これらは人間の環境への基本的要求と考兄られる。

2）環境への新たな期待

一方，令後の動向として強く現われてくると思われる 事項としては次のよらなものがあげられよう。

まず精神的文化的豊かさを求める傾向が一層強くなる であろ ${ }^{8)}$ 。その結果, 知的情報交換や学習・教化を目 的とする緑空間への要求が高まると思われる。すなわち 広場, 自然観賞・探索の場としての緑地が身近に必要と なってこよう。

次に居住環境において新しい人間関係の確立が求めら れてくる。コミュニティ形成のための相隣関係は市民意 識を基礎とするものでなければならない。たとえ同一量 の緑環境があったとしてもその地域に親しい人間関係が 存在するか否か, によって緑環境への満足度は異なって くる筈である。またかつてのアメリカに和けるようにコ ミュニティの核に近隣社交公園を有することは有効な方 法であると考えられ，今までわが国ではとかく整備の遅 れていた近隣公園・地区公園レベルの公園整備が推進さ れるであろう。

さらに人々の価值観の多様化, 生活様式の变化に対応 して居住疅境にも新たな質が期待されてくる。すなわち 安全で保健的で快適な環境を形成する緑ばかりでなく， 時には野生的で危険な自然の面を示すこと, あるいは単 一の機能をもつ緑から多㥞な機能・意味を内包する緑の 必要性がでてくる。この多目的ないしは多義的な緑は,
利用者がその求める意味に応じて利用できるタイプの緑 であり，いわば意味の宝庫としての総合的な緑である。 この代表的なものが都市林であろう。人々は都市林から 多様な意義と機能を抽出し利用することができるからで ある。価値観の多様化する時代には緑環境も多样な価值 をもったものにならざるを得ないのである。

安定化社会に拈いては仕事中心から仕事之家庭・個人 の雨立坴重視する方向になるであるう。それにともなっ て緑地も休養型からスポーツ等の動的レクリエーション を中心としたものやファァミリー型のものが要望されて くると思われる。同時に人々の行動圈が桩大することか ら緑のネットワークの整備が必要となってくる。公園緑 地系統を含めた緑環境システムがつくられ福はならなな い。

今後の社会動向の中で最も顕著なものは高齢化であ る。そのことは高㱓化社会にふさわしい環境の整備が必 要となることを示している。しかしながら環境整備の問 題は単に高粭層のみを対象とすべきものではない。次項 で述ベるようにライフサイクルに見合った緑環境を創出 する一環として把えられるべきものである。

以上，今後の予想される動向をみてきたが，特徴的な ことはかつてのように明確な具体的な課題，目磦を設定 し難くなってきたということである。とくに量的目標か ら質の向上および緑環境整備にかかわる周辺状況の整備 に重点が拁かれるようになるにしたがって，整備水準お よび到達目標のモデルは一律には定まらなくなってく る。その意味で個性化, 独自性が要求される時代になっ てきたといえる。このような時代では各々が自らの内に 課題を設定し解決していか朴ばならないであろう。

3）ライフサイクルと緑環境

緑環境に対する考光は生活体験に根ざす部分が大き い。とくに幼年時代の印象が原体験となってその後の緑 環境への考え方に影響を与えていることはしばしばみら れる。

一般に人々と緑環境との関係は一生のうちで 4 時期に 分けて把えるのが妥当であろう5。

第 1 は小児期の環境である。この時代は環境を自らが 選択することができない。地理的にも社会的にも所与の 環境の中で興味を引くものや感動を与えるものを見出す だけである。しかしこの時期の印象はいわば刷り込又の ような形で，後々まで緑環境へのイメージに無意識に動 くことになる。そしてこのような環境認識が次々の世代 に引き継がれていくならば，緑環境認識が遣伝的に継承 されることにつながっていくし，ていては緑に対する国 民的合意が形成されることになる。その意味で後世の緑 環境を豊かにするためにも小児期の緑環境を多様かつ豊 かにしておくことが必要である。このことが緑環境の永 続的維持に結びつくことになる。豊かな生物的環境に接 
することができることを是と見なせる精神的貴族を有成 する必要がある。子供時代の緑環境を魅力あるものとす るには身近な居住環境の中で緑の量を確保するばかりで なく線の質の充実をはかり, 子供たち汇新鮮な感動と発 見の喜びを与得るようにしなければならない。動物と の関倸, 季節の変化さらには自然のもつ危険性すら感得 できることも必要なのである。

次汇10代後半から結婚までの青年期の環境はまた違っ た内容をもつものとなろう。この時期は自らが主体的に 環境を把えることができるし，また対象となる緑環境の 筑囲も広域化する。体力的に最も恵まれた時期であるか ら求める緑環境もスポーツを中心とした空間が主対象と なる。また行動が広域化するから身近な緑環境の不足を 遠方に代替して求めることも行われる。その意味では周 木レクリエーション対象となるよらな大規模緑地の配備 と交通網の整備による緑地系統の整備が必要となろう。 この時期は自我の確立とともに緑環境への対応も多样化 する。すなわち多様な緑空間が要求されるが, それを機 能毎に用意するのではなく，多義的な緑（都市林など） として整備することも必要であろら。

第 3 は親としての時期である。この成壮年期の環境で は親の環境之子供の環境との両立がはかられることにな る。スタンプはこの段階の理想的な居住形態は庭付き一 户建の住宅であるといらず。それは親にとっての休養空 間と子供に之っての緑環境の悯方が身近に用意されてい るからであるら。持家政策の対象世代はこのような人々 である。しかしながら現実にはこのよらな条件はなかな か得られない。そこで児童公園, 近隣公園等の日常的利 用対象としての公園緑地の計画的整備が必要になってく る。居住環境の快適性の問題が重要な時期なのである。

最後法老年期の環境である。定年を迎え, 子供達も独 立した後での老夫婦の生活環境をどのように考えるかは これからの新しい課題である。庭の管理も体力的に難儀 になってくる人もいよう。この時期には都心の文化的刺 激や生活の利便さを求めて再び郊外から都心の共同住宅 へ㞔ってくる者もふえる。余睱を有效に利用できる文化 的環境, 趣味と適度な運動を生かせる自然的空間, 若者 との接触を含めだミュニケーションの場の確保が望ま れるであらう。そして軽い労働を通して社会的にも奉仕
できる機会に，恵まれるならば生きがいにもつながるで あろら。

このように世代毎で意味の異なった緑環境を意識的に 用意し，居住の仕方を時期汇合わせて変えるといら，い わば居住システムの流動化をはかることも今後の重要な 課題となってくると思われる。

\section{おわりに}

最後に今後の最大の課題の一つに後継者をいかに有て るかがある。

現在は混沌の時代といわれる。また将来の予測をたて 難い状況にもある。どのような目標をかかげて邁進すれ ばよいか，誰もが模索しているといってよい。そしてこ のことが次代の造園界を担う者の養成㲹も影響している とすれば，われわれは今何をなすべきであ万らか。後輩 達が造園といら職業に誇りをもって前進することができ るようになるためには, 先輩達が造園家としての自負を もって一生懸命努力している姿で示す以外ないのではな いだろらか。

\section{参考文献}

1) Ellenberg, H. : Grundlagen der Kartierung natürlicher Standortseinheiten, Raumforschung und Raumordnung 10(2), 59-62, 1950

2 ）橋本道夫: 人間環境之創造的思考, 環境情報科学 13(3), $2--5,1984$

3 ) 井于久登: 第 4 章課題, 「日本の造園」 88-102, 誠 文堂新光社, 1964

4) 同 ：1985年 I F L A 日本大会の意義と課題, 造固雑誌47(3)，193-195，1984

5 ) 同 : ライフスタイルと緑環境, グリーンェー シ , 133, 22-23, 1985

6 ）経済審議会：2000年の日本，13-14, 経済企曲庁, 1982

7 ) スタンプ (佐々林博訳) : 応用地理学, $75-77$, 古 今書院, 1972

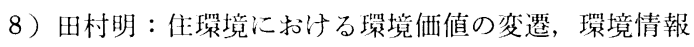
科学13(2), 44-47, 1984 